\title{
A comparison of the traditional casting method and the galvanoforming technique in gold alloy prosthetic restorations
}

\author{
Katarzyna Sarna-Bos ${ }^{1}$, Agata Batyra ${ }^{1}$, Justyna Oleszek-Listopad ${ }^{1}$, \\ Beata Piorkowska-Skrabucha ${ }^{1}$, Janusz Borowicz ${ }^{1}$, Jolanta Szymanska ${ }^{2 *}$ \\ ${ }^{1}$ Department of Prosthetic Dentistry, Medical University of Lublin, Poland \\ ${ }^{2}$ Chair and Department of Paedodontics, Medical University of Lublin, Karmelicka 7, 20-081 Lublin, Poland
}

\begin{tabular}{|c|c|}
\hline ARTICLE INFO & ABSTRACT \\
\hline $\begin{array}{l}\text { Received } 08 \text { July } 2015 \\
\text { Accepted } 15 \text { July } 2015\end{array}$ & \multirow{2}{*}{$\begin{array}{l}\text { Gold is a dental material with very good mechanical properties. It is also aesthetic } \\
\text { and biocompatible with the tissues of the oral cavity even at } 100 \% \text { purity. Prosthetic } \\
\text { restorations made of pure gold or its alloys can be practiced either through a normal } \\
\text { casting, as well as through using the galvanoforming technique. The electrolytic method } \\
\text { was first introduced into dentistry about } 20 \text { years ago and it allows for producing "pure" } \\
\text { gold (which means } 99.99 \% \mathrm{Au} \text { ). The lack of additions of other metals improves the } \\
\text { properties of dental prostheses, such as marginal tightness, esthetics, biocompatibility, } \\
\text { and it helps in eliminating any allergic reactions. The literature review presented in this } \\
\text { paper is a comparison of the traditional casting method with the newer galvanoforming } \\
\text { technique. }\end{array}$} \\
\hline $\begin{array}{l}\text { Keywords: } \\
\text { gold, } \\
\text { gold alloys, } \\
\text { galvanoforming } \\
\text { biocompatibility } \\
\text { fixed dentures. }\end{array}$ & \\
\hline
\end{tabular}

\section{INTRODUCTION}

The main aim of the contemporary rehabilitation of the stomatognathic system is to make dental prostheses more esthetic, functional and biocompatible. Gold is a material that has been known for hundreds of years and even though technological progress has caused various new materials to appear, gold alloys still remain the best choice. This is due to their biocompatibility with oral cavity tissues. It needs emphasizing that gold is widely used in the dental prosthetics. Removable dentures, where the surface permanently touching the oral cavity tissue, can be made of galvanized gold, as can fixed dentures and even some structures of implant systems [22]. Hence, gold can be considered a universal material, used in all types of dental prostheses [5,9].

There are two basic ways of making gold prosthetic restorations: the traditional casting method and the galvanoforming technique. The electrolytic method was introduced into dentistry about 20 years ago and it allows for processing "pure" gold (which means $99.99 \% \mathrm{Au}$ ) [16]. The lack of other metal additions improves the properties of future prosthetic dentures by improving marginal fit, esthetics, biocompatibility and the elimination of allergic reactions [15,22]. Both methods have their advantages and drawbacks. These should be given a closer look at by researchers.

\footnotetext{
* Corresponding author

e-mail: szymanska.lublin@gmail.com

tel.: +48601 165205
}

\section{The traditional casting method (lost-wax casting technique)}

The lost-wax casting technique is used in dentistry to produce inlays, onlays, overlays, all-metal crowns, porcelain-fused-to-metal crowns and components of partial removable dentures. Casting is a method that allows for making precise copies of a wax pattern of a prosthetic work by changing a wax model into a metal cast. The technique employed is known as the "lost-wax casting process". The name means that in this process, the wax, which is the model of the cast item, is totally burned away without leaving any residue, and then molten metal alloy (for instance gold alloy) fills this space during the casting process [11].

\section{Laboratory procedures}

1. Prepare a cast with a removable die of high strength dental stone, and model a previously planned restoration using casting wax:

a) prepare the abutment teeth - uncover the preparation margin, isolate it with a layer of spacer lacquer in order to create space $(20-35 \mu \mathrm{m})$ for the cementation of the final fixed denture on the patient's tooth [11],

b) produce a wax pattern by modeling the tooth in wax (the Adapta Deep Drawing System) or by modeling by way of utilizing a calibrated wax casting

2. Prepare a molding form by attaching sprue and sprue cone to the previously made wax pattern [17]. 
3. Ensure appropriate preparation of the wax structure for proper contact with the investment material, by covering it with the special substance to increase the surface tension and create a smooth model surface [11].

4. Replace the wax casting with metal alloy using the lost-wax casting technique:

a) place a previously prepared wax structure in a casting ring and invest (pour into the mold the investment material). Regarding gold alloys, the employed investment material has a mid melting point (temperature range $700-1200^{\circ} \mathrm{C}$ ). However, other widely available investment materials for both noble and non-noble metals can be utilized [11].

b) after the investment material has set, the casting ring should be placed within an oven and heated according to the manufacturer's recommendations: the burn-out process leaves a void that would be filled with the liquid gold alloy [11].

c) cast the metal structure - this should be undertaken right after the wax-burning procedure has been accomplished, while the ring is still hot. When casting noble alloys, it is recommended to use a crucible former with a graphite addition so as to heat up only a particular amount of the alloy. Note: if the metal alloy is not sufficiently heated, it may not fill in the form totally. On the other hand, if it has been heated up too much, it might cause the investment material to crack.

5. Cooling - Polak suggests that the ring should be cooled slowly - by being kept in a hot oven [17]. Other authors suggest that it need only be cooled at room temperature or in a heated bath. Cooling the form too quickly might lead to deterioration of its properties, particularly, its endurance [26]. Free the cast metal structure from the investment material. Subsequently, the metal form should be cleaned using a sandblasting machine (particles of aluminum oxide with the diameter of 110-125 $\mu \mathrm{m}$ and 2-bar pressure) and then placed in an acid bath for 5 to 10 seconds (sulphuric acid solution).

6. Seat the cast metal structure on the die and mechanically prepare the casting. The marginal fit of a prosthetic restoration made with the traditional casting technique ranges between 50 and $120 \mu \mathrm{m}[8,10]$. At this stage, sprue and the sprue cone are cut off. One of the disadvantages of this traditional method of casting is that the residue of the alloy (sprue and sprue cone) cannot be used again, which means that about $25 \%$ of the material is lost [19].

7. Remove the excess metal, thus forming the final shape of the structure. Eventually, it will also be sandblasted again, using an aluminum oxide, and then polished. Following this, it will be delivered to a dentist for a try-on procedure [11].

\section{Galvanoforming}

The galvanoforming technique was invented in 1961, in Australia. It is based on the process of electrolysis [18]. The monometal $(99.5-99.9 \% \mathrm{Au})$ produced in the process is resistant to thermal, chemical and mechanical factors. Hence, the corrosion risk that the alloy additions might cause is eliminated [10,21,26]. Furthermore, galvanized 24-carat gold has much better biological and physicochemical properties than cast gold alloys. This technique is most commonly used to make inlays, onlays, overlays, crowns, short-span bridges, telescoping crowns and implant-supported fixed dentures $[2,4,23]$.

\section{Laboratory procedures}

1. Prepare the cast by way of utilizing a removable die of high strength dental stone and correct potential undercuts or porosity in the region of the removable die [21].

2. Isolate and cover the layer of the prepared die with spacer lacquer [13].

3. Fabricate a duplicate out of epoxy-resin die (deemed the 'duplicated micromodel') [13].

4. Place a copper brad (a cathode) on the die under the tooth preparation margin and coat the die with a thin layer of silver lacquer to enable electrical conductivity $[1,8]$.

5. Immerse the duplicate die in a galvanizing bath containing electrolyte and ammonium gold sulphite [8].

6. Set out proper parameters for the process: utilize the recommended electric current intensity, the appropriate bath temperature, as well as the suitable time interval. This last is dependent on the desired thickness of the metal structure. For instance, within a 10 hours, $0.2 \mathrm{~mm}$ of gold is laid down. During a 1 second interval, about 30 billion gold atoms appear on the cathode's surface [21].

7. Complete the galvanization process, rinse the die, remove the gold structure and rinse this as well [13].

8. Remove the residue of the lacquer through the process of sandblasting, using aluminum oxide powder, and then etch it by way of employing a solution of nitrogenous acid (50\%), subsequently, fit the gold cup [13].

9. Prepare the gold substructure for ceramic veneering.

a) sandblast the substructure surface with corundum sand (50 $\mu \mathrm{m}$ diameter) under 1.5 bar pressure and clean it using hot water steam (stream abrasion technique)

b) Note: there is no surface enabling a chemical bonding of metal with ceramics which means that a special bond (pure Au with ceramics) needs to be applied twice. This action improves the strength of the bonding between the gold substructure and the ceramics. Moreover, it becomes the intermediate layer between two phases during the burning process $[13,21]$.

\section{Discussion}

The galvanoforming technology allows for obtaining particular prosthetic restoration elements of very regular and fine-grained structure. This makes them much more resistant to fractures or mechanical impact. These advantages enable dentists to make thin-walled dentures (around 0.2 $\mathrm{mm}$ ) whilst keeping a high level of precision and hardness $[5,19]$. Furthermore, it makes for very efficient preparation of the hard tooth tissue, and this translates into better esthetic effect in the case of the final prosthetic restoration. The high marginal fit of the gold substructure (about $20 \mu \mathrm{m}$ ) is also its advantage [24,26].

The traditional metal casting technique has a range of advantages as well. One of these is that there is a layer of oxides established that provides a stable connection with the veneering ceramics and brings about higher endurance against fracture, in comparison with the galvanoforming 
technique. A comparison of prosthetic fillings made by the traditional casting process and by the galvanoforming technique is presented in Table 1.

Table 1. A comparison of gold prosthetic restorations made by the traditional casting method and by galvanoforming

\begin{tabular}{|c|c|c|}
\hline Feature & $\begin{array}{c}\text { Traditional casting } \\
\text { method }\end{array}$ & $\begin{array}{c}\text { Galvanoforming } \\
\text { technique }\end{array}$ \\
\hline Degree of purity & $\begin{array}{l}\text { lower, possible } \\
\text { dirt from the } \\
\text { crucible }\end{array}$ & higher \\
\hline Material consumption & higher & lower \\
\hline Thickness & even $0.5 \mathrm{~mm}$ & $0.2-0.4 \mathrm{~mm}$ \\
\hline Weight & $1.0 \mathrm{~g}$ at minimum & about $0.5 \mathrm{~g}$ \\
\hline Porcelain mass: metal thickness ratio & $4: 1$ & $1.7: 1$ \\
\hline $\begin{array}{l}\text { The size of grains in the internal } \\
\text { structure }\end{array}$ & $400 \mu \mathrm{m}$ & $50 \mu \mathrm{m}$ \\
\hline Hardness & $25-28 \mathrm{HV}$ & $100-150 \mathrm{HV}$ \\
\hline Surface of metal oxides & present & absent \\
\hline Dental plaque formation & more frequent & less frequent \\
\hline Color & white-gold & gold \\
\hline Porcelain discoloration & $\begin{array}{c}\text { possible } \\
\text { (depends on the } \\
\text { alloy parts) }\end{array}$ & $\begin{array}{c}\text { possible } \\
\text { only when the } \\
\text { oven was dirty }\end{array}$ \\
\hline Marginal fit & $\begin{array}{l}50-120 \mu \mathrm{m}, \\
\text { up to } 200 \mu \mathrm{m}\end{array}$ & $20 \mu \mathrm{m}$ \\
\hline Biocompatibility & $\begin{array}{l}\text { depends } \\
\text { on the alloy }\end{array}$ & almost $100 \%$ \\
\hline Fracture resistance & higher & lower \\
\hline Preparation of tooth tissues & higher & lower \\
\hline Amount of dental technician's work & high & low \\
\hline Costs & lower & higher \\
\hline
\end{tabular}

Making prosthetic restorations by way of the galvanoforming technique requires the use of specialist devices (electrolyte baths, microprocessing units), reagents and other supplementary materials. The necessity of these obviously boosts the costs of the whole procedure, at least when compared with the traditional casting method. At the moment, the galvanization process itself is conducted using digitallycontrolled devices [10]. In the case of the traditional casting method, only items common to the jewelry business are needed.

Galvanoforming allows for obtaining completely "pure" structures. The crucibles and compounds used in the traditional technique may cause an increase in contamination, the amount of which goes up every time the crucible is used. Moreover, employing the galvanoforming technique means a forty percent lower consumption of gold - which translates into huge material savings [8]. In addition, there is no contamination - which positively affects the rates of allergization [15,22].

Galvanized structures are thin-walled and their thickness or weight are much reduced. One crown weighs about $0.5 \mathrm{~g}$, whilst with regard to the traditional casting method, it would be $1.0 \mathrm{~g}$ [19]. Low thickness is another advantage of a golden substructure (0.2-0.4 mm), which translates into much more space for the veneering material (even $1.0 \mathrm{~mm}$ ) [10]. For comparison, the thickness of a substructure made of golden alloys should be $0.5 \mathrm{~mm}$ at least [21].

A substructure produced by way of the galvanoforming technique is tantamount to generating a much better visual effect, as well as having more profound colors [15]. The ratio of porcelain to the thickness of the metal structure of a crown is $1.7: 1$, whilst in case of galvanized prosthetic restorations, it is $4: 1[6,7,14]$. This means that there is a possibility of a much more efficient preparation of the tooth tissues [21]. This is extremely important with regard to crowns made for smaller teeth, such as mandibular incisors, for instance [8].

Galvanized gold has a uniform structure with ordered grains (about $50 \mu \mathrm{m}$ ), whilst in the case of traditional casting of prosthetic restorations, the rate can be almost $80 \%$ higher, reaching $400 \mu \mathrm{m}$. Furthermore, using the traditional technique might create some contraction cavities or empty spaces without metal. This phenomenon is not present in restorations made by way of the galvanoforming technique $[10,17]$.

The internal structure of any item influences its hardness, which means that the regular crystal structure of galvanized gold is even four times harder than in the situation of gold processed by way of the traditional casting method $[19,25]$. Using the Vickers' scale, it is 100-150 HV and 25-28 HV, respectively $[1,21]$.

Oxides tend to appear on the surface of the structures made as a result of galvanoforming. This improves the connection between the metal and the ceramic components [26]. If they are absent, it is necessary to use special bonding agents and bonding constructions that connect the ceramic with gold in a micromechanical retention $[1,8,10]$. At the same time, the lack of new ions can eliminate its deteriorating influence on the periodontium. Clinical observations have demonstrated that minimal deposition of dental plaque on the galvanized structures allows for keeping marginal gingiva in good condition [10].

The esthetic factor is a significant advantage shared by both methods. The metallic shine of the subgingival area is eliminated by the warm color of gold [3,20,24]. Moreover, various alloying additions can change the color of the structure. In the case of the galvanoforming method, this usually generates a warm golden color. Beyond this, firing porcelain onto gold, can bring about slight changes in color. This might happen when a gold alloy (which contains copper or silver) is used. When the foundation is made using the galvanized method, the color can only change because of some contamination being present in the porcelain firing (copper fumes, for instance) [26].

Relatively high (up to $20 \mu \mathrm{m}$ ) marginal fit in galvanized prosthetic restorations is yet another advantage [6,7,14,22]. This provides great protection against failing dental cement, caries creation or inflammations of the periodontium. High tightness is also required in the case of undertaking more precise work, such as fabricating telescopic crowns. According to different sources, full gold crowns are much worse when it comes to marginal fit - mainly to 50-120 $\mu \mathrm{m}$ [1], and sometimes even to $200 \mu \mathrm{m}[6,7,14]$.

During the galvanization process, 24-carat gold structures are produced, which means they are $100 \%$ biocompatible $[1,2]$. They have much better physicochemical or biological properties than those made of gold alloys, where corrosion resistance may be different and dependent on the amount of the non-noble metals inside $[2,3,12,20,24]$. However, prosthetic restorations made of gold alloys (formed by way of the traditional casting method) are much more resistant to fractures, hence, they are regularly employed in long-span dental bridges procedures [19]. 
Finally, the traditional casting method takes much more work and effort in order to generate a useful product. The laboratory procedures consist of numerous stages and there is less automation than in the case of the galvanoforming technique $[19,26]$ (Tab. 1).

\section{CONCLUSION}

Prosthetic restorations made of pure gold through the galvanoforming process are much better than those made with the traditional casting method. However, the high price of material and the fact that the restorations require some special devices to be used remain to be the main obstacles.

\section{REFERENCES}

1. Biały M., Dąbrowa T., Więckiewicz W.: Galwanoforming jako alternatywa dla złożonych uzupełnień protetycznych. Dent. Forum, 41, 69, 2013.

2. Biewer P.: Development of the G.E.S. electroforming technique: biocompatible, corrosion-free production of telescopic crowns. J. Dent. Technol., 16, 24, 1999.

3. Biewer P.: Galvanosekundark ronnen sind in der Passung unschlagbar. DZW, 8, 18, 2000.

4. Ernst K. K.: Uzupełnienia złote. Wykonanie galwanicznej protezy teleskopowej. Quintessence. Dent. Technol., 9, 7, 2004.

5. Gnadlinger K.,: Legierung: Komposit und Keramik-alles passt zusammen. DZW SPEZIAL - Legierungen, 1, 45, 1999.

6. Hammerle C. H., Mesaric W., Lang N. P.: Marginal fit of porcelain crowns with galvanized frames. Schweiz Monatsschr Zahnmed, 104, $740,1994$.

7. Holmes J. R., et al.: Marginal fit of electroformed ceramometal crowns. Int. J. Prosthodont., 5, 111, 1996.

8. Jedynak B., Szczyrek P.: Zastosowanie techniki galwanoformingu w protetyce stomatologicznej. Protet. Stomatol., 60, 32, 2010.

9. Koch J.H., Fuming A.: Presskeramik: Die Krone von Funktionen und Asthetik. Zahnarzt \& Praxis, 1, 14, 2002.

10. Majewski S.: Nowe technologie wytwarzania stałych uzupełnień zębowych: galwanoforming, technologia CAD-CAM, obróbka tytanu i współczesne systemy ceramiczne. Protet. Stomatol., 57, $125,2007$.
11. Ołdak W.: Wykonanie estetycznej protezy stałej - mostu okrężnego. Etapy postępowania - cz. II. Nowocz. Tech. Dentyst., 4, 9, 2005.

12. Otulakowska-Skrzyńska J., Krysiński Z.: Korozja biologiczna metalicznych materiałów dentystycznych w środowisku jamy ustnej. Implantoprotet., 5, 16, 2004.

13. Pawłowski W.: Wykonanie estetycznego uzupełnienia w przednim odcinku górnego łuku zębowego na podbudowie ze złota galwanicznego. Nowocz. Tech. Dentyst., 2, 10, 2006.

14. Petteno D., et al.: Comparison of marginal fit of 3 different metalceramic systems: an in vitro study. Int. J. Prosthodont., 13, 405, 2000.

15. Pietruska M., Pietruski J.: Zastosowanie techniki galwanoformingu w protetyce. Protet. Stomatol., 54, 352, 2004.

16. Pietruski J.K., Pietruska M.D.: Materiały i technologie używane we współczesnej protetyce stałych uzupełnień zębowych - wady i zalety przedstawione na podstawie przeglądu piśmiennictwa i doświadczeń własnych. Stomatol. Estet., 9, 89, 2013.

17. Polak A.: Teoretyczne podstawy i praktyczne wskazówki z zakresu odlewnictwa. Nowocz. Tech. Dentyst., 2, 28, 2005.

18. Rogers O. W., Armstrong B. W.: Electroforming a gold matrix for indirect inlays. J. Prosthet. Dent., 11, 959, 1961.

19. Rosak P., et al.: Galwanoforming a tradycyjny odlew. Nowocz. Tech. Dentyst., 5, 42, 2011

20. Schuler Dental: Sparsames Feinstrahlgerat, biologisch abbaubare Gussmuffel-Einlage und biokompatible Vergoldungselehtrolyte. DZW Zahn Technik, 5, 37, 1999.

21. Stwora I., Zieliński K., Kokot T.: Technika galwanoformingu w protetyce stomatologicznej. Nowocz. Tech. Dentyst., 6, 52, 2010.

22. Tejchman H., Bogurski M., Nawrocki M.: Możliwości zastosowania techniki galwanicznej w stomatologii - obserwacje wstępne. Protet. Stomatol., 52, 291, 2002.

23. Tietmann C., Broseler F.: Enhanced periodontal response and esthetics of implant - supported bridge by the use of galvanoforming technique: case report. Clin. Implant. Dent. Relat. Res., 4, 53, 2002.

24. Wagner R.: Speziell zum System gehorende optimierte Legirung neu auf dem Markt. DZW Zahn Technik, 11, 32, 2000.

25. Vence B. S.: Electroforming technology for galvanoceramic restorations. J. Prosthet. Dent., 77, 444, 1997.

26. Zielińska A., Wojtczak A., Suchorzewski A.: Stałe uzupełnienia protetyczne na podbudowie ze złota - porównanie galwanoformingu z metodą tradycyjnego odlewu. Dent. Forum, 35, 59, 2007. 